\title{
Financial Flexibility, Investment Ability and Firm Value: Evidence from Firms with Spare Debt Capacity
}

\author{
Maria-Teresa Marchica and Roberto Mura*
}

\begin{abstract}
We document, for the first time, that a conservative leverage policy directed at maintaining financial flexibility can enhance investment ability. Our analysis reveals that following a period of low leverage, firms make larger capital expenditures and increase abnormal investment. We find that these new investments are financed through new issues of debt. The impact of financial flexibility is both statistically significant and economically sizeable. Further, long-run performance tests reveal that financially flexible firms not only invest more, but also invest better. Our results are consistent with the view that financial flexibility in the form of untapped reserves of borrowing power is a crucial missing link in capital structure theory.
\end{abstract}

There is a puzzling empirical regularity in the capital structure literature. Many firms appear to borrow less than the dominant theories predict. In his influential paper, Graham (2000) finds that "Paradoxically, large, liquid, profitable firms with low expected distress costs use debt conservatively." He also reports that this conservative behavior appears to be persistent. Similar issues are discussed, among others, by Minton and Wruck (2001) and Strebulaev and Yang (2008).

Recent survey evidence has shed some light on this matter (Bancel and Mittoo, 2004; Brounen, De Jong, and Koedijk, 2004; Graham and Harvey, 2001; Pinegar and Wilbricht, 1989). These studies suggest that it is financial flexibility that primarily drives chief finance officers' leverage choices. Respondents say that flexibility is very important in enabling their companies to undertake investment in the future, when asymmetric information and contracting problems might otherwise force them to forego profitable growth opportunities. In other words, companies may adopt a conservative leverage policy to maintain "substantial reserves of untapped borrowing

We thank Bill Christie (editor) and the anonymous referee whose comments have significantly helped to improve the paper. We are indebted to Michael Brennan, Harry and Linda DeAngelo, Marie Dutordoir, Mara Faccio, Annalisa Ferrando, Andrea Gamba, Ian Garrett, Marc Goergen, Alessandra Guariglia, John Hutton, Evangelos Kharalambakis, Meziane Lasfer, WeiMin Liu, Kasper Nielsen, Aydin Ozkan, Ser-Huang Poon, Norman Strong, Alex Taylor, Alex Triantis and Sergey Tsyplakov for helpful discussions. We also thank all the participants in the FIRS 2008, FMA USA 2008, FMA Europe 2008, EFA USA 2007, FMA Europe 2007, EFMA 2006, and FMA USA 2006 “Top Ten Percent" Special Session, and PFN 2006 meetings for their insightful comments. We are also grateful to the participants in the seminar series at European Central Bank, Cass Business School, Manchester Business School, the Nottingham Department of Economics, Sheffield Management School and the University of Verona for their useful suggestions. Kind help from David Roodman of the Center for Global Development, Roger Walsh of Bureau Van Dijk, Derek Rouse of Hemscott Plc Support Team and Francesco Cerlienco of Reuters is also acknowledged. We are also grateful to Wendy Jennings, Pam Losefsky, and Alison Walters for editorial help. The usual disclaimer applies.

${ }^{*}$ Maria-Teresa Marchica is a Lecturer in Finance at the Manchester Business School, University of Manchester, Manchester, England M13 9PL, UK. Roberto Mura is a Lecturer in Finance at the Manchester Business School, University of Manchester, Manchester, England M13 9PL, UK. 
power" (Modigliani and Miller, 1963) allowing them to access the capital market in the event of positive shocks to their investment opportunity set.

However, as yet, little is known about financial flexibility. How can we identify financially flexible (FF) firms? Does financial flexibility really improve the investment ability of companies? Ultimately, is this strategy value-enhancing for firms? This paper provides empirical evidence to address these questions.

First, we identify "FF" firms by focusing on firms with spare debt capacity (SDC). ${ }^{1}$ We estimate a leverage equation from which we calculate the predicted level of debt. Since the demand for financial flexibility is an unobservable factor, it ends up in the residual of the estimated model, and generates a systematic deviation between observed and estimated leverage. For this reason, we propose to capture the demand for financial flexibility indirectly, using negative deviations from estimated target leverage. We classify a firm as FF if it has spare debt capacity for a minimum number of consecutive years.

Second, we test econometrically whether this degree of financial flexibility has any impact on investment ability. The prediction is that, in the presence of market frictions, firms that anticipate valuable growth options in the future may respond by pursuing a policy of low leverage for a number of years. In this way, FF firms have enough spare borrowing power to be able to raise external funds, and to invest more in the years following the conservative financial policy. To test this hypothesis, we specify a q-model of investment augmented by our FF dummy, plus an interaction term with cash flow. According to our flexibility argument, the FF dummy should have a positive and significant impact on capital expenditures. In addition, to the extent that FF firms can, after a period of conservative borrowing, more easily raise external funds to finance their projects, their investment ability should be less dependent on internal funds. As a consequence, we would expect a lower sensitivity of investment to cash flow.

We provide evidence that a conservative leverage policy can help firms attain a degree of financial flexibility. Our results indicate that FF companies exhibit enhanced investment ability. Our tests reveal that an average company that maintains a spare debt capacity policy for three years (FF3) can increase its capital expenditures by around 37\%. Further, our tests reveal that the longer the period of low leverage, the lower the economic impact of FF status on the firm's investment ability. For instance, a company that maintains spare debt capacity for at least six years typically increases its capital expenditures by around $28 \%$. This may be because the ability of managers to anticipate future growth opportunities decreases the further into the future they go. These results are robust to the method we follow to classify FF firms.

Also, we find that companies finance new investments by means of positive net debt issues. This provides strong evidence that companies sacrifice borrowing today to enhance their ability to seize better growth opportunities in the future. This result is also robust when we take into account other financing strategies that may achieve financial flexibility, such as a cash policy. For instance, when we account for the presence of (excess) cash in the investment decisions, or when we consider leverage net of cash, as in Bates, Kahle, and Stulz (2009), we still find an economic impact similar to our main results.

Third, we test the long run performance effect of this strategy. A number of papers suggest that managers prefer to keep debt ratios low to reduce risk and to protect their undiversified human

${ }^{1}$ Firms may achieve financial flexibility in other ways. For instance, Denis and Sibilkov (2009) demonstrate how higher cash holding helps constrained firms to invest in value-enhancing projects. We do address this issue later in the text and show that our results are robust even when we control for the effect of internal funds. Powers and Tsyplakov (2008) stress the role of make-whole call provisions that allow firms to have the flexibility of retiring their debt early. Jagannathan, Stephens, and Weisbach (2000) underline how stock repurchases (as opposed to cash dividends) allow firms a higher degree of financial flexibility. 
capital (Fama, 1980), or to alleviate the pressure that comes with interest payment commitments (Jensen, 1986). Alternatively, managers may choose to increase debt levels in a manner that allows them to pursue empire building (Zwiebel, 1996) and to minimize takeover risk (Berger, Ofek, and Yermak, 1997). In other words, conservative leverage and high investment may be symptoms of greater agency costs.

To distinguish these various potential influences and to investigate whether a financing policy aimed at financial flexibility is value-enhancing, the last step of the analysis examines its impact on both long run performance and post-investment profitability. First, we use both the capital asset pricing model (CAPM) and the Fama and French (1993) three-factor model to investigate the behavior of Jensen's (1986) alpha for FF firms in the long run, after they acquire flexibility status or, alternatively, after they make abnormal investments. If our flexibility hypothesis is correct, we expect this policy to be value-enhancing. If, on the other hand, this policy is an expression of greater agency conflicts, we should find a negative effect on firm performance. Then, we compare the company's operating performance before and after the FF status is acquired, and before and after FF companies make abnormal investments.

Our findings strongly indicate that companies that acquire financial flexibility through spare debt capacity are not only able to invest more, but also seem to invest better. Long run performance analysis consistently returns positive and statistically significant results for Jensen's (1986) alpha using either the CAPM or the Fama and French (1993) three-factor model up to 60 months after the FF status identification, irrespective of the method employed to classify FF firms. Economically, the impact on the returns of an FF firm also seems sizeable. According to the figures obtained from the Fama and French (1993) three-factor model, FF companies outperform the market by almost 30 basis points per month, which corresponds to about $7.1 \%$ in the first two years. Similarly, we find that our FF firms outperform the market when we measure their long run performance after they have made abnormal investments. The economic impact implied by Jensen's (1986) alpha suggests an abnormal long run performance of approximately $13.24 \%$ in the first two years. Further, firms experience an increase of more than $18 \%$ in operating performance within two years of the acquisition of the FF status and a staggering increase of $38 \%$ in their profitability within two years after an abnormal investment. This enhances the strength of our conclusions, and also allows us to rule out the possibility that managerial entrenchment drives low leverage and higher investments.

Our study contributes to the literature in a number of ways. We provide direct evidence, for the first time, of the value of financial flexibility to companies by studying the impact this policy has on investment ability and long run performance. These are very important results within recent developments in the capital structure literature. According to DeAngelo and DeAngelo (2007), "financial flexibility is the critical missing link for an empirically viable theory [of capital structure]." We provide very sound evidence that complements this hypothesis. A large fraction of observed leverage is left unexplained by conventional theories of capital structure. Our inability to "measure" the FF factor ex ante causes a systematic spread between observed and predicted leverage. In this way, our work also provides a rationale for debt conservativism that tallies with the theoretical predictions recently proposed by Almeida, Campello, and Weisbach (2009) and DeAngelo, DeAngelo, and Whited (2010), and may provide an explanation of the so-called low leverage puzzle.

The remainder of the paper is organized as follows. In Section I, we describe the data and present the main hypotheses. In Section II, we present the empirical results and all the robustness tests performed, while in Section III, we discuss our conclusions. 


\section{Data and Hypotheses}

\section{A. Data Collection and Sampling}

We construct our sample from all UK listed firms present in Datastream from 1965 to 2008. We exclude financial firms as their capital structure is likely to differ from that of the other firms in our sample. Since both leverage and investment models include the lagged dependent variable as a regressor, we exclude companies with fewer than two consecutive years of data. Firms with missing values of relevant variables are also excluded. All data are trimmed at the $1 \%$ level to reduce the impact of outliers. Our results are largely unaltered when we winsorize the data at the $1 \%$ level rather than trim it. This results in an unbalanced panel of 47,553 observations for 4,290 firms.

For the performance analysis, we collect monthly returns data for individual stocks in the sample for the FTSE All Share Index, FTSE Small Cap, and FTSE 100 Indexes to proxy portfolios of small and large firms, and for the FTSE Global Value and FTSE Global Growth Indexes to proxy portfolios of high and low book-to-market stocks. We collect the United Kingdom three-month Treasury bill rates to approximate the risk free interest rate.

In an attempt to control for the agency costs of equity in the leverage equation, we collect, by hand, information regarding ownership by managers, ownership by nonmanagers, and board composition for a randomly selected subsample of firms for the period 1991-2001. Data are collected from the Price Waterhouse Corporate Register (December issue). After screening the data for possible errors and matching it with the accounting information from Datastream, we have an unbalanced panel of 677 firms and 5,660 observations. For this subsample of companies, we also collect and match information on debt rating (Reuters) and bankruptcy risk using FAME, which is part of the Bureau van Dijk Electronic Publishing's databases, with a coverage specific to UK firms (Lemmon, Roberts, and Zender, 2008). ${ }^{2}$

\section{B. Identification of Financially Flexible Firms}

Recent survey studies of capital structure choices provide strong evidence that the single most important determinant of leverage decisions by firms is the desire to maintain financial flexibility (Graham and Harvey, 2001; Bancel and Mittoo, 2004). However, as we argued above, since there is no well-defined measure of flexibility in the literature, this is an unobservable factor that depends largely on managers' assessment of future growth options. Consequently, this factor will end up in the residual of the model, where it will generate systematic deviations between observed and estimated leverage. For this reason, we propose to indirectly capture the effect of financial flexibility using deviations from predicted target leverage.

In the first step of the analysis, we identify firms with spare debt capacity using Frank and Goyal's (2009) baseline model, which includes median industry leverage, market-to-book ratio, size, tangibility, profitability, and expected inflation. Frank and Goyal (2009) use the data from the Livingston Survey to proxy for expected inflation. Similar data are not available for the entire time series for the United Kingdom and, as such, we use T-bills instead. As Frank and Goyal (2009) state "[...] replacing expected inflation with the Treasury bill rate is unlikely to matter since they are highly correlated."

We follow the seminal work of Arellano and Bond (1991) by first differencing the model, and then using suitable lagged levels of the dependent variable as instruments. We estimate all leverage models using the GMM-SYS methodology. This allows us to control simultaneously for

\footnotetext{
${ }^{2}$ We thank Francesco Cerlienco from Reuters for kindly providing the data.
} 
the endogeneity of the regressors and for fixed effects that may be correlated with the explanatory variables (Blundell and Bond, 1998; Lemmon et al., 2008). Inclusion of the lagged dependent variable allows for the firm's targeting behavior. ${ }^{3}$ The baseline model we estimate is the following:

$$
\begin{aligned}
L E V_{i t}= & \alpha_{1} L E V_{i t-1}+\beta_{1} \text { Industry Leverage }+\beta_{2} M t b v+\beta_{3} \text { Size }+\beta_{4} \text { Tangibility } \\
& +\beta_{6} \text { Expected Inflation }+\eta_{i}+\eta_{t}+u_{i t} .
\end{aligned}
$$

We then compare the fitted values from the regression analysis with the actual values and define as SDC those firms that exhibit a negative deviation between actual and predicted leverage. As discussed above, we expect the systematic component of these deviations to be due to the unobserved effect of financial flexibility in the leverage model. To minimize the impact of noise, we require the deviation to be larger than $10 \%$. We perform a number of robustness tests in which we require a minimum deviation of either $5 \%$ or $25 \%$. Alternatively, we follow Harford (1999) and require observed leverage to be 1.5 standard deviations lower than the predicted value.

Finally, to classify a firm as FF, we require it to have SDC for a minimum number of consecutive periods. This ensures that we are indeed observing a policy, not just a transitory shock to the capital structure of the firm. As a baseline specification, we use FF3, which is the FF dummy that takes a value of one when we observe at least three consecutive periods in which the firm is classified as SDC. There is no theoretical rationale for choosing a specific time length. Therefore, to assess whether the results are sensitive to the choice of time horizon, we use a number of different proxies, from a minimum of two to a maximum of six consecutive years of leverage conservatism.

This approach is not free of drawbacks. The most serious is that the choice of leverage model may affect the estimated target and the deviation from it. This, in turn, would influence the classification of firms and the subsequent investment results. To minimize the possibility that the results are driven by the choice of a specific leverage model, we take two important steps. First, we perform numerous robustness tests using different leverage models. In particular, we try to control for other factors that may allow firms to attain a degree of financial flexibility, the most important of which is financial slack. Second, we follow an alternative approach similar to Minton and Wruck (2001) and classify firms as low leverage when their debt ratio is in the bottom $20 \%$ of the distribution. ${ }^{4}$ We refer to this as the percentile methodology.

\section{Financial Flexibility and Investment Ability}

In their seminal paper, Modigliani and Miller (1963) noted that despite the existence of some tax advantages for debt financing, firms tend not "to use the maximum possible amount of debt in their capital structure" due to limitations by lenders leading to "the need for preserving flexibility." In the modified version of the pecking order theory (Myers, 1984), firms have two main reasons to restrain themselves from issuing debt: 1) to avoid the costs of financial distress, and 2) to maintain financial slack. Taking these ideas as a starting point, we test the hypothesis that in the presence of market frictions, firms that anticipate valuable growth options in the future may respond by pursuing a policy of low leverage for a number of years. As in Myers (1984), reserves of borrowing power enable FF firms to raise external funds and to invest more in the years following conservative financial policy.

\footnotetext{
${ }^{3}$ Numerous survey studies corroborate the idea that firms have a target capital structure. Graham and Harvey (2001) report that $37 \%$ of US firms have a flexible target debt ratio, while a further $35 \%$ have a stricter target. Bancel and Mittoo (2004) and Brounen et al. (2004) report similar figures for the United Kingdom.

${ }^{4}$ Mikkelson and Partch (2003) classify as "high cash" those companies that hold more than $25 \%$ of their assets in cash and equivalents. See also Iona, Leonida, and Ozkan (2004) for UK firms.
} 
As a first step, we explore the behavior of FF firms over time via a detailed descriptive analysis. If our prediction is correct, we should observe that FF firms invest less during the conservative leverage period, and increase their investments after reaching FF status. Also, to the extent that companies sacrifice borrowing today to enhance their ability to seize better growth opportunities in the future, FF firms should show an increase in their abnormal investments. Finally, we should observe material increases in net issues of debt (new debt issues minus retirements) around the time when companies increase their investment as they are expected to finance these with the spare debt capacity resulting from conservative leverage.

To test our predictions, we employ a q-model of investment in which capital expenditures are regressed on Tobin's $q$ and cash flow (Cleary, 1999; Alti, 2003; Brown and Petersen, 2009). Also, we augment the model by including our flexibility dummy, and we add an interaction term with cash flow to test whether FF firms have, indeed, enhanced investment ability and a lower sensitivity of investment to cash flow.

We employ the GMM technique in a dynamic framework similar to Bond et al. (2003) to control for endogeneity and fixed effects. The estimated model is as follows:

$$
\begin{aligned}
\text { Investment }_{i t}= & \alpha \text { Investment }_{i t-1}+\beta_{1} \text { Cash Flow }_{i t-1}+\beta_{2} \text { Tobin's }_{i t} \\
& +\beta_{3} F F_{i t}+\beta_{4}\left(\text { Cash Flow }_{i t-1} \times F F_{i t}\right)+\eta_{i}+\eta_{t}+v_{i t},
\end{aligned}
$$

where Investment is the ratio of investments in fixed assets to capital stock; Cash Flow is the ratio of operating profits before tax, interest, and preference dividends plus depreciation of fixed assets to capital stock; Tobin's $q$ is the ratio of book value of total assets minus book value of equity plus market value of equity to capital stock; $\eta_{i}$ is a fixed effect; $\eta_{t}$ is a time-specific effect; and $v_{i t}$ is a disturbance term assumed to be serially uncorrelated with mean zero. ${ }^{5}$

If our hypothesis is correct, the FF dummy should have a positive and significant impact on the capital expenditures of firms. Furthermore, the interaction term between FF and cash flow should be negative since given their spare debt capacity, these companies can raise external funds to finance projects and are less dependent on their internal funds.

\section{The Value of Financial Flexibility}

As the last step of our analysis, we examine the impact of a policy of financial flexibility on long run performance to investigate whether this policy is value-enhancing for firms. One limitation of long run performance analysis lies in the potential cross-sectional correlation of events. This is particularly relevant in our case, as a certain leverage policy aimed at implementing an investment strategy might also be determined by the business cycle. Therefore, to analyze the long run performance of FF firms, we adopt a time-series analysis. We analyze the monthly excess returns of the equally weighted portfolios of firms that achieved FF status at the beginning of the preceding 24 (36 or 60) months. We adopt both the CAPM and the Fama and French (1993) three-factor models

$$
R_{p F F, t}-R_{f, t}=\alpha_{p F F}+\beta_{p F F}\left(R_{m, t}-R_{f, t}\right)+\varepsilon_{p F F, t}
$$

\footnotetext{
${ }^{5}$ Capital stock $(K)$ is measured using the perpetual inventory method. For the first observation, we assume the replacement cost equals the historic cost of total net fixed assets, adjusted for inflation. For the following observations, we apply a standard perpetual inventory method as follows: $K_{i t}=K_{i t-1}(1-\delta)+I_{i t}$, where $\delta$ is the rate of depreciation assumed to be 0.08 (Bond et al., 2003).
} 
where $R_{p F F, t}$ denotes the month $t$ return of an equally weighted portfolio of all firms identified as financially flexible $(p F F)$ in the preceding 24 (36 or 60) months; $R_{f, t}$ is the United Kingdom three-month Treasury bill rate converted to a monthly rate of return; $R_{m, t}$ is the return on the FTSE All Share Index in month $t ; S M B_{t}\left(H M L_{t}\right)$ is the return difference between a portfolio of small and large (high and low book-to-market) firms. If FF firms are outperforming the market, then the intercepts $\alpha_{p F F}$ and $a_{p F F}$ in the time-series regressions should be significantly greater than zero, suggesting that a FF policy is value-enhancing.

As a further test, we follow Denis and Denis (1993) and we analyze trends in operating performance by comparing the profitability before and after the FF status has been acquired, and before and after abnormal investments have been made. This allows us to test whether this policy is also value-enhancing on the operating side.

\section{Empirical Results}

\section{A. Leverage Models}

We start our analysis by estimating the leverage models, which are instrumental to the identification of SDC firms. In the first column of Table I, we report results for the baseline model. In the second and third columns, we present results for augmented leverage models controlling for a variety of other factors that can potentially contribute to leverage decisions (see Section $\mathrm{E}$ later in the text). Our GMM estimation reveals that the coefficient on lagged leverage in all the specifications is positive and significantly different from zero. The adjustment coefficient $\lambda$ $(1-\hat{\alpha})$ for the baseline model is about 0.37 . This provides evidence that the dynamic nature of our model is not rejected. Moreover, this indicates that companies take about three years to close the gap with their target corroborating our choice of examining the leverage behavior of firms for three consecutive years. This result is very similar to that reported recently for US firms by Flannery and Rangan (2006).

The results across all specifications are in line with most of the findings in the capital structure literature and, as such, are not commented upon for brevity (Rajan and Zingales, 1995; Flannery and Rangan, 2006; Frank and Goyal, 2009).

\section{B. Characteristics of Financially Flexible Firms}

As discussed above, once the leverage models have been estimated, we classify FF firms on the basis of the availability of spare debt capacity captured by negative deviations between observed and predicted leverage. As a baseline specification, the dummy FF takes on a value of one when we observe at least three consecutive periods in which the firm is classified as SDC. The first observation in the series is not available because the data are first differenced to run the leverage models using GMM. Further, since to assign FF status, we require a minimum of three consecutive observations in which firms are classified as SDC, the first employable observation to classify FF companies is the fourth one. This is the main reason why the total sample goes from 4,290 firms available for the leverage equations to 2,541 in the investment equation. Comparative detailed descriptive statistics reveal that the two samples are highly comparable, and the procedure we follow does not bias the sample in any direction.

Table II reports some descriptive statistics through which we try to understand the characteristics of the sample companies. We have 1,178 companies classified as FF, 966 never classified as 


\section{Table I. Leverage Models}

This table presents the estimations used to predict target capital structure. Book Lev is the ratio of total debt to total assets; Market Lev is the ratio of total debt to book value of total assets minus the book value of equity plus the market value of equity; IndustLev is the median industry leverage by SIC code and by year. Industry is defined at the four-digit SIC code level. $M t b v$ is the ratio of book value of total assets minus the book value of equity plus the market value of equity to book value of total assets; Size is the natural logarithm of total assets in 1991 prices; Tangibility is the ratio of fixed assets to total assets; Profitability is the ratio of earnings before interest, tax, and depreciation (EBITD) to total assets; Inflation is proxied using the three month treasury bill rate; Cash is the ratio of total cash and equivalents to total assets; Maturity is the ratio of loans repayable after one year to total debt; Dividends is the ratio of ordinary dividends to total assets; Tax is total tax charge to total assets; Ndts is depreciation to total assets; Managerial Ownership is the sum of ordinary shareholdings held by executive directors (\%); Blockholding is the sum of the nonmanagerial shareholdings above 3\%; Board Composition is the proportion of nonexecutives to the total number of directors. We show regression coefficients with heteroskedasticity robust standard errors. $p$-Values are provided in parentheses.

\begin{tabular}{|c|c|c|c|}
\hline & Baseline & Extended & Extended Plus Ownership* \\
\hline Book Lev ${ }_{t-1}$ & $\begin{array}{c}0.626 \\
(0.000)\end{array}$ & $\begin{array}{c}0.611 \\
(0.000)\end{array}$ & $\begin{array}{c}0.637 \\
(0.000)\end{array}$ \\
\hline IndustBookLev & $\begin{array}{c}0.421 \\
(0.000)\end{array}$ & $\begin{array}{c}0.469 \\
(0.000)\end{array}$ & $\begin{array}{c}0.316 \\
(0.000)\end{array}$ \\
\hline$M t b v$ & $\begin{array}{l}-0.005 \\
(0.004)\end{array}$ & $\begin{array}{r}-0.049 \\
(0.000)\end{array}$ & $\begin{array}{r}-0.004 \\
(0.077)\end{array}$ \\
\hline Size & $\begin{array}{c}0.002 \\
(0.007)\end{array}$ & $\begin{array}{c}0.005 \\
(0.000)\end{array}$ & $\begin{array}{c}0.011 \\
(0.001)\end{array}$ \\
\hline Tangibility & $\begin{array}{c}0.025 \\
(0.077)\end{array}$ & $\begin{array}{c}0.070 \\
(0.017)\end{array}$ & $\begin{array}{c}0.051 \\
(0.051)\end{array}$ \\
\hline Profitability & $\begin{array}{r}-0.009 \\
(0.000)\end{array}$ & $\begin{array}{r}-0.002 \\
(0.000)\end{array}$ & $\begin{array}{r}-0.088 \\
(0.055)\end{array}$ \\
\hline Inflation & $\begin{array}{l}0.81 \\
(0.001)\end{array}$ & $\begin{array}{c}0.61 \\
(0.008)\end{array}$ & $\begin{array}{c}0.77 \\
(0.000)\end{array}$ \\
\hline Cash & & $\begin{array}{r}-0.075 \\
(0.000)\end{array}$ & $\begin{array}{r}-0.099 \\
(0.005)\end{array}$ \\
\hline Maturity & & $\begin{array}{c}0.025 \\
(0.000)\end{array}$ & $\begin{array}{c}0.042 \\
(0.000)\end{array}$ \\
\hline Dividends & & $\begin{array}{l}-0.416 \\
(0.001)\end{array}$ & $\begin{array}{r}-0.265 \\
(0.000)\end{array}$ \\
\hline $\operatorname{Tax}$ & & $\begin{array}{c}0.007 \\
(0.000)\end{array}$ & $\begin{array}{c}0.002 \\
(0.085)\end{array}$ \\
\hline Ndts & & $\begin{array}{c}-0.142 \\
(0.000)\end{array}$ & $\begin{array}{r}-0.233 \\
(0.004)\end{array}$ \\
\hline Managerial Ownership (\%) & & & $\begin{array}{c}0.0004 \\
(0.002)\end{array}$ \\
\hline Blockholding (\%) & & & $\begin{array}{l}0.000073 \\
(0.420)\end{array}$ \\
\hline Board Composition & & & $\begin{array}{c}0.055 \\
(0.000)\end{array}$ \\
\hline Observations & 47,553 & 47,553 & 5,660 \\
\hline Number of Firms & 4,290 & 4,290 & 677 \\
\hline Firm Fixed Effects & Yes & Yes & Yes \\
\hline Year Fixed Effects & Yes & Yes & Yes \\
\hline
\end{tabular}




\section{Table II. Descriptive Statistics}

This table reports the means and $t$-tests on the equality of means of some of the key characteristics of our sample firms. FF refers to Financially Flexible firms. It is a dummy that takes the value of one when we observe at least three consecutive periods in which the firm is classified as SDC; NFF stands for Never Financially Flexible (i.e., those firms that never show FF status over the entire estimation period); AFF stands for Always Financially Flexible (i.e., those firms with a low leverage status for the entire estimation period). Book Lev is the ratio of total debt to total assets; Market Lev is the ratio of total debt to book value of total assets minus the book value of equity plus the market value of equity; $M t b v$ is the ratio of book value of total assets minus the book value of equity plus the market value of equity to book value of total assets; Size is the natural logarithm of total assets in 1991 prices; Tangibility is the ratio of fixed assets to total assets; Profitability is the ratio of earnings before interest, tax, and depreciation (EBITD) to total assets; Cash is the ratio of total cash and equivalents to total assets; Debt Maturity is the ratio of loans repayable after one year to total debt; Dividends is the ratio of ordinary dividends to total assets; Earnings Volatility is the standard deviation of cash flow in the previous five years scaled by average total assets over the same period; Bankruptcy Risk (Z-Score) is defined following Altman (1968) (0.012* (current assets - current debt)/total assets $+0.014^{*}$ retained earnings/total assets $+0.033^{*}$ earnings before interest and taxes/total assets $+0.006^{*}$ equity/total debt $+0.010^{*}$ sales/total assets); Bankruptcy Risk (Quiscore) is a variable provided by the FAME data set from Bureau van Dijk. The score ranges from 0-100, where larger figures represent lower bankruptcy risk. Debt Rating data were kindly provided by Reuters. The figures represent the average rating, which is a numeric variable that assumes a value of 100 for AAA firms, 10 for $\mathrm{CCC}$ or below, and 0 for unrated firms. Investment grade is defined as a value 70 and above (S\&P rating of BBB or higher). Managerial Ownership is the sum of ordinary shareholdings held by executive directors (\%); Blockholding is the sum of the nonmanagerial shareholdings above 3\%; Board Composition is the proportion of nonexecutives to total number of directors.

\begin{tabular}{lcccc}
\hline \hline & FF & NFF & AFF & $\begin{array}{c}\text { Test of Difference in Means FF } \\
\text { versus NFF }(\boldsymbol{p} \text {-value) }\end{array}$ \\
\hline Book Lev & 0.09 & 0.26 & 0.04 & $(0.000)$ \\
Market Lev & 0.08 & 0.23 & 0.04 & $(0.000)$ \\
Mtbv & 1.40 & 1.32 & 1.57 & $(0.001)$ \\
Size & 12.42 & 12.24 & 10.87 & $(0.855)$ \\
Tangibility & 0.35 & 0.32 & 0.36 & $(0.000)$ \\
Profitability & 0.10 & 0.04 & 0.02 & $(0.000)$ \\
Cash & 0.07 & 0.05 & 0.09 & $(0.000)$ \\
Debt Maturity & 0.45 & 0.51 & 0.44 & $(0.000)$ \\
Dividends & 0.025 & 0.016 & 0.027 & $(0.000)$ \\
Earnings Volatility & 0.09 & 0.14 & 0.10 & $(0.000)$ \\
Bankruptcy Risk (Z-Score) & 5.00 & 2.26 & 34.75 & $(0.023)$ \\
Bankruptcy Risk (Quiscore) & 67.11 & 61.43 & 70.90 & $(0.108)$ \\
Debt Rating* & 78.12 & 70 & 85.61 & $(0.000)$ \\
Managerial Ownership (\%)* & 9.71 & 10.85 & 8.40 & $(0.000)$ \\
Blockholding (\%)* & 31.11 & 36.45 & 22.73 & \\
Board Composition* $_{\text {Total Firms }}^{*}$ & 0.46 & 0.42 & 0.42 & \\
\hline
\end{tabular}

${ }^{*}$ Indicates a subsample of firms for which we hand collected ownership information.

financially flexible in all time periods (NFF), and 397 always classified as financially flexible (AFF). We separate AFF from FF companies since their actual leverage is always less than the predicted level. Therefore, it does not seem that these firms are following a conservative leverage policy to boost their future investment ability as FF firms are. Unreported further investigation of the data reveals that the United Kingdom has very similar numbers of zero leverage and almost 
zero leverage firms to those reported in Strebulaev and Yang (2008). The vast majority of these belong to our AFF cluster of firms.

As expected, FF firms borrow less than NFF firms, although the subgroup of AFF firms demonstrates the lowest levels of borrowing since they are always underleveraged. FF firms seem to have a small edge in terms of growth options over NFF firms as the test of difference in means reveals a $p$-value of zero. FF firms also seem to have more tangible assets than the NFF while little difference appears to emerge in terms of company size. In line with the leverage regression results, the descriptive analysis indicates that companies with greater profitability or cash holding tend to borrow less. FF firms also appear to have a lower fraction of long-term debt than NFF firms. This combination of lower leverage and higher short-term debt may reflect the attempt by FF firms to minimize underinvestment problems (Johnson, 2003; Datta, Datta, and Raman, 2005; Marchica, 2007). However, FF firms tend to pay higher dividends than NFF firms. This is in line with the evidence provided by Graham and Harvey (2001) who report financial flexibility to be more important to dividend paying companies. An important difference is detected in the volatility of earnings. It might be argued that firms with more uncertain earnings value financial flexibility more, but our results offer no support for this conjecture as FF firms have more stable earnings than NFF firms. This result is, however, consistent with the expectation of a positive link between dividend payout and stability of earnings (Bancel, Bhattacharyya, and Mittoo, 2009).

We also inspect some features that may reveal the bankruptcy risk the firm is exposed to, and that could, therefore, generate an incentive to behave (more) conservatively in their leverage policy. When we calculate the Altman z-score (1968), we find that FF firms are indeed less likely to file for bankruptcy, and the difference from NFF firms is statistically significant at any conventional level. As a further robustness test, we collect the variable "Quiscore," a measure of bankruptcy risk provided by the FAME-Bureau van Dijk Database. The score ranges from 0 to 100 , where like the z-score, larger figures represent lower bankruptcy risk. Again, FF firms have a higher value than NFF firms, and the difference is statistically significant. As a final step, we collect debt rating information. Similar to what Faulkender and Petersen (2006) document for the United States, very few UK companies have a debt rating. However, the figures document that the average rating for FF firms is 78.12 versus 70 for NFF firms. The difference is again statistically significant at the $1 \%$ level. ${ }^{6}$ These preliminary tests suggest that FF firms are not more exposed to market imperfections than other companies. Also, when we turn to ownership and governance characteristics, we find that no cluster of firms seems particularly affected by "entrenched managers." Average board ownership is around $10 \%$ for all groups, which, according to the study by Mura (2007) on the performance of UK firms, falls inside the alignment area. Similar conclusions can be drawn from the figures on board composition and average blockholding.

We also inspect the data to see if there is any particular clustering at the industry level. We follow the two-digit SIC code classification and analyze industry concentration. A large proportion of FF firms, $41 \%$, belongs to the manufacturing sector (SIC Codes 20-39). The service industry is represented at approximately $18 \%$ (SIC Codes $70-89$ ), while we also find approximately $17 \%$ and $12 \%$ in the trade and the transportation, communications, electric, gas, and sanitary services, respectively (SIC Codes 50-59 and 40-49). Finally, mining and construction account for about $12 \%$ of FF firms (SIC Codes 10-17), while agriculture, forestry, and fishing has less than $1 \%$.

${ }^{6}$ The rating is a numeric variable that assumes a value of 100 for AAA firms, 10 for CCC or below, and 0 for unrated firms. Investment grade is defined as the value 70 and above (S\&P rating of BBB or higher). 


\section{Understanding the Behavior of FF Firms}

Figure 1 presents graphs describing firms' choices over time. We start by defining $t$ as the time at which FF firms are assigned a value of one after three years of SDC. Then, we analyze their behavior in terms of investment and financial decisions from $t-2$ to $t+2$. Prior to $t, \mathrm{FF}$ firms appear to be investing less than in $t+1$ and $t+2$ (Panel A). In particular, they appear to experience an important and sudden increase in their investments between $t-1$ and $t$.

This is further corroborated when we turn to industry-adjusted investment $\left(\operatorname{Adj}_{i t}\right)$ in Panel B. The pattern of firm investment "in excess" of the industry mean confirms that FF firms feature a marked increase in their investment, in particular between $t-1$ and $t$. In Panel C, we report figures for (industry adjusted) abnormal investment. These are capital expenditures that are larger in value than the norm in the firm's life (Mayer and Sussman, 2004). To identify these spikes, we generate a proxy for "normal investment activity" (NIA) by calculating the average value of industry-adjusted investments $\left(A d j I_{i t}\right)$ over three year periods, but excluding the central year; that is, $N I A_{i, t}=\frac{A d j I_{i, t-1}+A d j I_{i, t+1}}{2} .^{7}$ This represents the norm (industry-adjusted) investment for the company. Then, we compare the company's (industry-adjusted) investment at time $t$ with $N I A_{i t}$ and define an investment as abnormal if its value is at least twice the value of NIA. In other words:

$$
\text { Abnormal Investment }_{i, t}=\left\{\begin{array}{rl}
\operatorname{Adj} I_{i, t} & \text { if } \operatorname{Adj} I_{i, t} \geq 2 N I A_{i, t} \\
0 & \text { otherwise }
\end{array} .\right.
$$

This procedure ensures that we are capturing investments that are larger than the company's norm, but it also allows us to control whether the firm is also spending more than its competitors. Once the abnormal investments have been identified for each FF firm, we plot their average values before and after the firm is assigned FF status. Panel $\mathrm{C}$ indicates that, around $t$, FF firms experience a very significant increase in their abnormal investments. For instance, on average, abnormal investments increase from 0.021 in $t-1$ to 0.027 in $t+1$, or by about $27 \%$. This may support the hypothesis that FF firms have used their preserved borrowing power through a conservative leverage policy, and sacrificed some current investment, to be able to pursue larger future growth options.

Panels D and E shed more light regarding how firms finance these investments. We document a sharp increase in their total borrowing between $t-1$ and $t+2$ (Panel D), which corresponds to a decline in the gap between actual and predicted leverage (Panel E). From time $t$, FF firms are much closer to their (estimated) target, as the values for the deviations are close to zero. Panel F confirms this trend, as FF firms appear to markedly increase new net debt issues between $t-1$ and $t$, leading to the closure of the deviation from the (estimated) target leverage. This further corroborates our initial hypothesis that, after a period of conservative borrowing, FF firms are better placed to exploit the external capital markets.

One argument that may confute our hypothesis is that firms restrain their borrowing, but use equity issues to invest. For instance, Mayer and Sussman (2004) and Tsyplakov (2008) document that equity is the preferred choice for small firms' financing abnormal investment, while profitable and large firms have a clear preference for debt over equity. DeAngelo and DeAngelo (2007) argue that if the probability of sizeable future capital needs is large, managers may issue equity rather than exhaust debt capacity. To control for this possibility, we analyze the trends in net equity issues. Panel G illustrates that firms do not appear to use new equity issues to finance

\footnotetext{
${ }^{7}$ The same exercise was performed using five rather than three years, and reached similar conclusions.
} 
Figure 1. Firm Behavior Over Time

These figures present an analysis of Financially Flexible firms' choices over time, where FF is calculated from the baseline specification. At time $t, \mathrm{FF}$ is a dummy equal to one if a company has a negative deviation from its target larger than at least $10 \%$ of all undershooting firms for three consecutive years, and zero otherwise. We then plot firm characteristic before and after this time (from $t-2$ to $t+2$ ). Investment is the ratio of investment to capital stock; Industry-Adjusted Investment is the deviation of Investment from the industry mean; Abnormal Investment is defined over a pattern of three years of industry-adjusted investment data. The average value of investments is calculated in the extreme years $\left(N I A_{i t}=\left(\operatorname{AdjI} I_{t-1}+\operatorname{AdjI} I_{t+1}\right) / 2\right)$. Thus, there is a spike in this pattern only if the investment value in the central year is at least twice the average of the extremes; Leverage is the ratio of total debt to total assets; Deviation is the difference between the actual and predicted level of leverage for each firm; Net Debt Issues is the ratio of net debt issued in each year to total assets; and Net Equity Issues is the ratio of net equity issued in each year to total assets Cash is the ratio of total cash and equivalents to total assets; Profitability is the ratio of earnings before interest, tax, and depreciation (EBITD) to total assets.

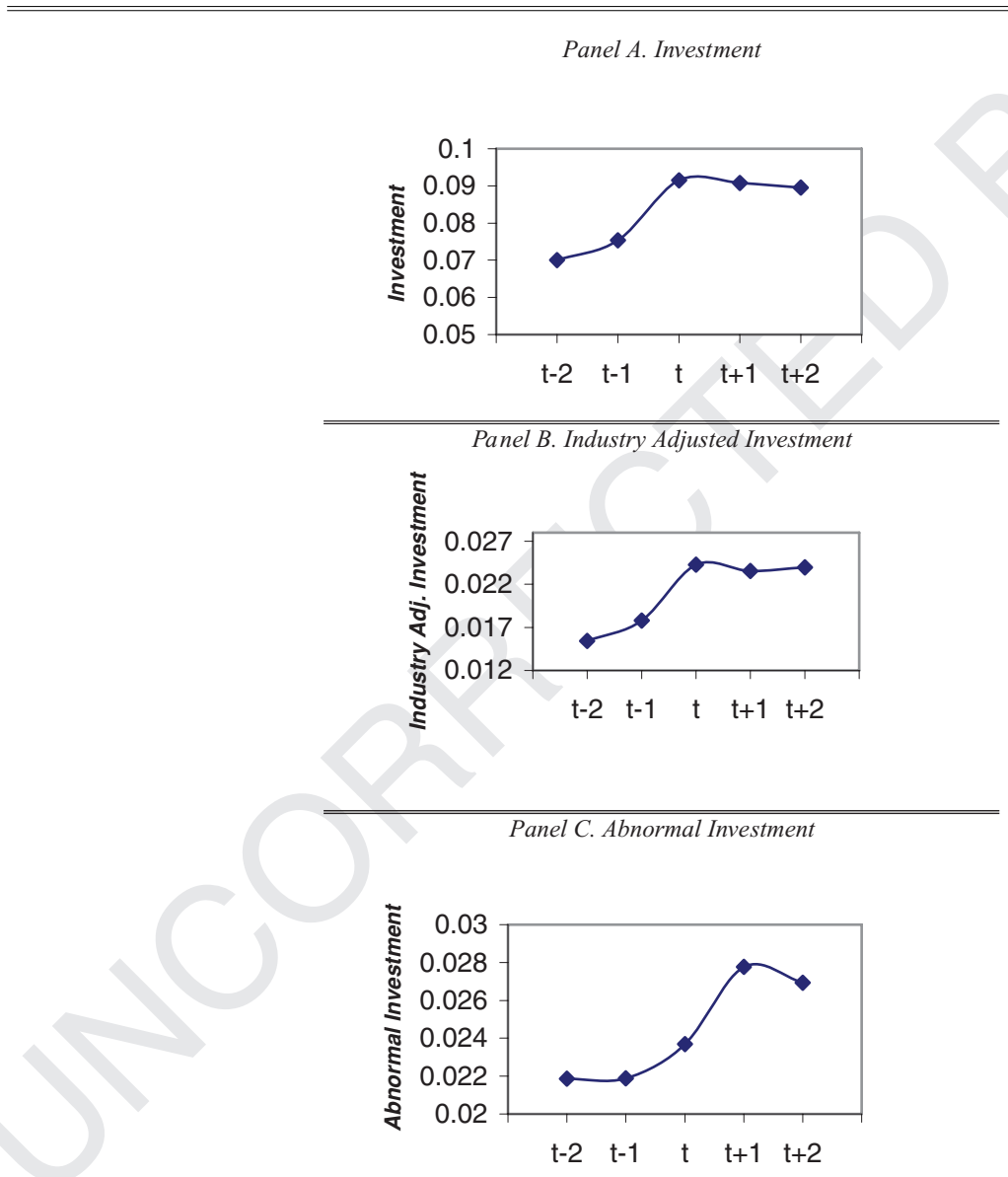

(Continued)

new investments. Rather, FF firms seem to undertake share repurchases. This trend is in line with recent evidence regarding the UK market by Oswald and Young (2004).

In Panel $\mathrm{H}$, we observe a sharp drop in their cash position between $t-1$ and $t+1$, where $t$ is the moment they are classified as FF. Cash drops by about $16 \%$, from $7.40 \%$ in $t-1$ to 
Figure 1. Firm Behavior Over Time (Continued)

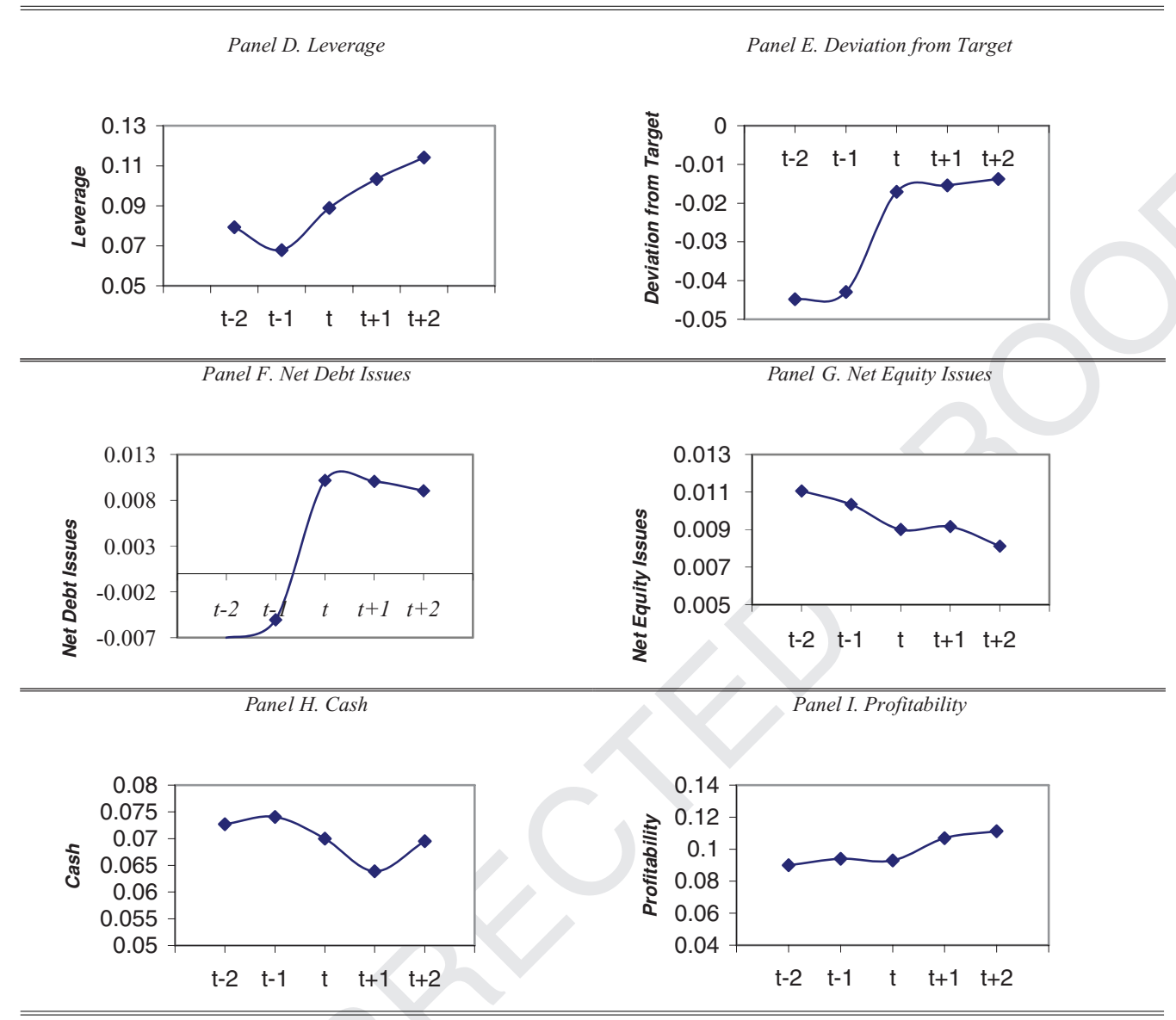

$6.31 \%$ in $t+1$. This may indicate that FF firms also use some of their liquid assets against their investment opportunities. Profitability, on the other hand, displays an increasing trend which does appear to increase markedly after $t$ going from $9.4 \%$ to $10.7 \%$ between $t-1$ and $t+1$ (Panel I).

As a preliminary test of our hypothesis, we analyze whether the differences in investment and abnormal investment across time are also statistically significant. In Table III, we present a number of tests performed across different specifications of the FF dummy. The main difference lies in the threshold imposed on the negative deviation from target leverage to classify a firm as $\mathrm{SDC}$. For $\mathrm{FF}(5 \%)$, the threshold is $5 \%$; $\mathrm{FF}(10 \%)$ is our "baseline" specification of the $\mathrm{FF}$ dummy in which a firm is first classified as SDC if it has a minimum of $10 \%$ negative deviation from the estimated target leverage. $\mathrm{FF}(25 \%)$ and $\mathrm{FF}(1.5 \mathrm{SD})$ are $\mathrm{FF}$ dummies resulting from a minimum deviation of $25 \%$ and 1.5 units of standard deviation, respectively. It can be seen that regardless of the approach we follow to classify a firm as FF, we always find that investment, and abnormal investment in particular, demonstrates a marked and statistically significant increase after the FF status has been achieved. For instance, for the baseline specification, we find an 
Table III. Investment and Abnormal Investment Changes Over Time

This table reports the changes in investment and abnormal investment before and after the financial flexibility status is acquired and presents $t$-tests on the equality of means. The central observation $t$ corresponds to the moment when FF firms are assigned a value of one. FF is a dummy equal to one if a company has a negative deviation from its target for three consecutive years, and zero otherwise. $F F(5 \%)$ is a dummy equal to one if a company has a negative deviation from its target larger than at least $5 \%$ for at least three consecutive years. $F F(10 \%)$ is a dummy equal to one if a company has a negative deviation from its target larger than at least $10 \%$ for at least three consecutive years. $F F(25 \%)$ is a dummy equal to one if a company has a negative deviation from its target larger than at least $25 \%$ for at least three consecutive years. $F F(1.5 S D)$ is a dummy equal to one if a company has a negative deviation from its target larger than at least 1.5 units of standard deviation for at least three consecutive years. Investment is the ratio of investment to capital stock; Abnormal Investment is defined over a pattern of three years of industry-adjusted investment data. The average value of investments is calculated in the extreme years $\left.\left(N I A_{i t}=A d j I_{t-1}+A d j I_{t+1}\right) / 2\right)$. Thus, there is a spike in this pattern only if the investment value in the central year is at least twice the average of the extremes.

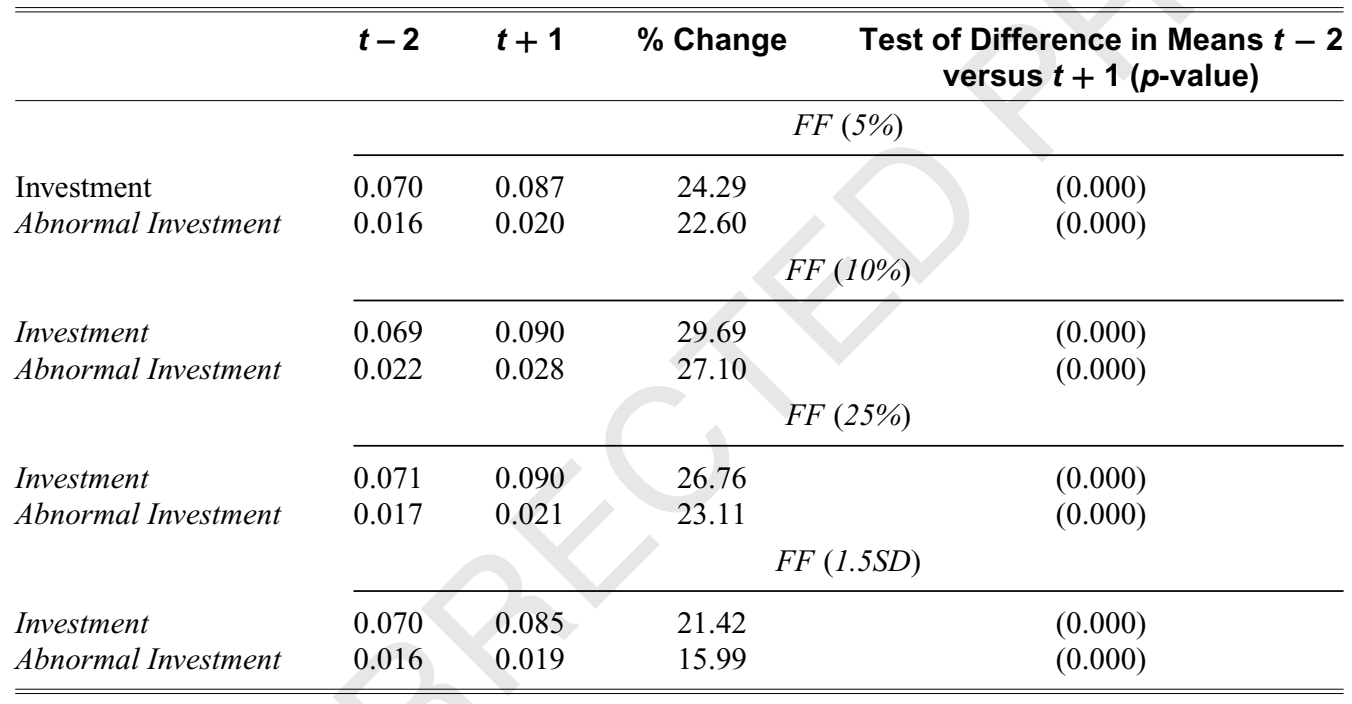

increase of about $30 \%$ in Investment and $23 \%$ in Abnormal Investment between $t-2$ and $t+1$.

In a further test, we isolate FF firms that survive for a minimum of 21 years, and plot their deviation from target leverage between $t-10$ and $t+10$, where $t$ is now the time when we observe an abnormal investment. This allows us to observe more closely the rebalancing behavior of leverage after the company has borrowed to finance the new large investment opportunity. Figure 2 reports that after the large investment is made, companies momentarily overshoot their target leverage. The observation corresponding to $t$ is the only one in the positive quadrant indicating a positive deviation from target leverage (i.e., overshooting). However, we also observe an immediate and opposite trend that takes the firm back below its estimated target. It seems to take approximately $3 / 4$ years for the firm to adjust (at least partly) and go back to the pre-jump levels. For instance, in $t+6$, the observed deviation $(-0.00743)$ is of similar magnitude to the corresponding $t-6$ value $(-0.0071)$. Similar results hold if we look at longer periods. The average deviation observed in $t-10$ is about -0.0104 whereas the corresponding value for $t+10$ is -0.0101 . This strongly corroborates the view that this large increase in debt to finance 
Figure 2. Long-Term Rebalancing of Capital Structure

This figure presents a long-term analysis of the rebalancing of capital structure of Financially Flexible firms where FF is calculated from the baseline specification. FF is a dummy equal to one if a company has a negative deviation from its target larger than at least $10 \%$ of all undershooting firms for three consecutive years, and zero otherwise. The central observation $t$ corresponds to the moment when FF firms make abnormal investments. We then plot the deviation from the target leverage from 10 years before to 10 years after (from $t-10$ to $t+10$ ). Abnormal investments are defined as follows: we generate a proxy for "normal investment activity" (NIA) by calculating the average value of industry-adjusted investments over three-year periods, but excluding the central year. This represents the norm (industry-adjusted) investment for the company. Then, we compare the company's investment at time $t$ with $N I A_{i t}$ and define an investment as abnormal if its value is at least twice the value of NIA and zero otherwise. Deviation is the difference between the actual and predicted level of leverage for each firm.

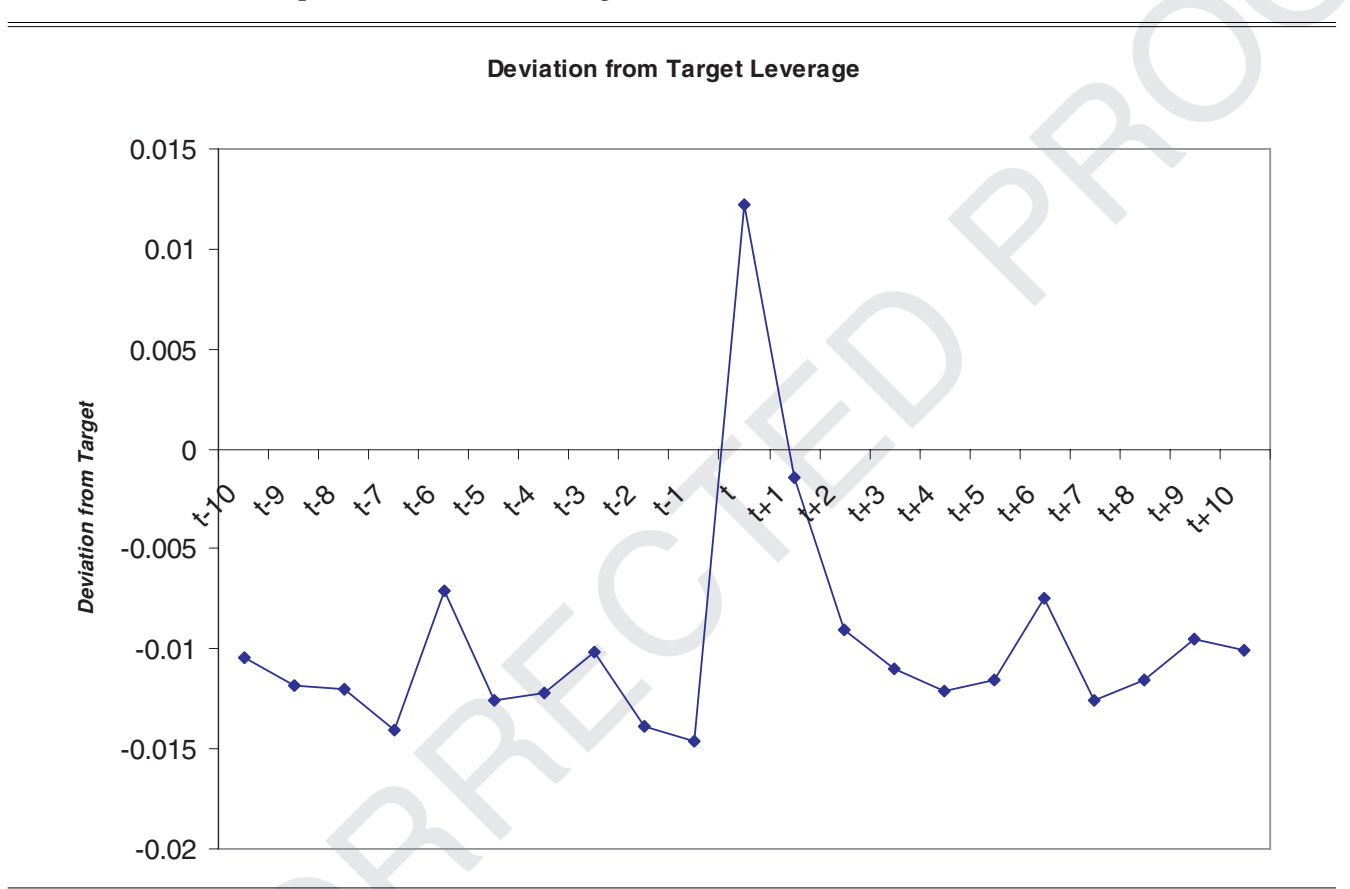

the new investment represents a temporary deviation from the long-term low leverage target to which the company reverts. This is consistent with the argument of DeAngelo et al. (2010) who maintain that the target is made of two components, a permanent and a transitory one. The former is the long run target companies are at before the jump and revert to after the large investments are made. The temporary deviation from this long run target is the transitory component allowing firms to actually carry out these abnormal investments.

The result we report is in line with Graham (2000) who reports that companies that preserve spare debt capacity to boost future investments tend to preserve substantial flexibility even in the periods after the investments have been made.

These are all very significant pieces of evidence and they confirm our initial hypothesis that at least some companies sacrifice current borrowing, and use this spare debt capacity to be able to afford larger (and possibly better) investment tomorrow. This lends strong empirical support to the survey evidence regarding capital structure. A financial flexibility strategy appears to improve 
the ability of firms to invest in and "pursue new projects when they come along" (Graham and Harvey, 2001).

\section{Investment Models}

We now turn to the investment model estimations. Having defined the FF dummy in the way we describe it in Section B, it is worth underlining that in the q-model, we investigate the correlation between investment at time $t$ and the dummy FF defining leverage conservativism preceding the investment decision (i.e., between $t-3$ and $t-1$ ). This should address the concern that the FF dummy (and, consequently, leverage) is endogenous to investment.

Table IV indicates the results of different specifications of the investment model including the calculation of the FF dummies using the target methodology with Frank and Goyal's (2009) baseline book-leverage model discussed above. In Panel A, we report tests in which the FF dummies are defined on the basis of SDC spanning between two and six years. In Panel B, we report further tests where the FF dummy is always defined on three years of SDC, but we require different thresholds in the deviation from target, similarly to what we described above $(5 \%, 25 \%$, 1.5 standard deviations). In line with most of the literature in this field (i.e., Cleary, Povel, and Raith, 2007), we observe a positive and significant relationship between Investment and Tobin's $q$, consistent with the prediction that growth opportunities play a relevant role in investment decisions. The coefficient on cash flow is always positive and significant suggesting that the presence of capital market imperfections may result in firms relying, at least partially, on internal funds to invest.

The dummies indicating FF status are positive and statistically significant across all specifications indicating that these companies invest more after a period of conservative leverage. Further, we find that the investment sensitivity to cash flow, as represented by the interaction between FF dummies and cash flow, is always negative and statistically significant. This result suggests that FF companies are less exposed to capital market imperfections, and that their ability to invest is, at a minimum, no more jeopardized by asymmetric and agency costs problems than it is for other firms. The impact of the FF status dummy is also economically sizeable. Indeed, ceteris paribus, an FF company with average cash flow (approximately 0.17 ) increases its investment by about 0.029 in absolute terms (FF3). ${ }^{8}$ This is a striking increase given that the average ratio of investment to capital stock is 0.079 . In other words, an average firm can invest approximately $37 \%$ more after acquiring financial flexibility status. ${ }^{9}$

As discussed above, for robustness purposes, we test for various spans of conservative leverage and various thresholds of deviation from target leverage to define FF. A low leverage policy for three years seems to yield the strongest economic impact, which tends to decrease almost linearly with time. This may reflect the fact that the ability of managers to foresee growth options decreases, the further away these are in the future. Alternatively, this could represent firms whose growth options did not materialize to the extent originally expected. Therefore, they did not need to relinquish their FF status for a longer period. The results are similar, albeit slightly smaller, when we use market rather than book leverage. For instance, the economic impact for FF3 is estimated at approximately $32 \%$.

Evidence from Panel B is very similar to that in Panel A although the results stemming from an FF defined on the basis of very small deviations, $\mathrm{FF}(5 \%)$, seems to yield the smallest economic

${ }^{8}$ Following Wooldridge (2000): $0.034 \times 1-0.028 \times 0.167=0.029$.

${ }^{9}$ The economic impact is of similar magnitude when we focus on the median firm. For instance, the corresponding value for FF3 in Table IV is $45.98 \%$. 


\section{Table IV. Investment Models}

This table presents GMM results for the q-model of investment with financial flexibility status dummies computed from the estimation of the "baseline" book leverage model (Table I column one). The dependent variable is Investment, defined as the ratio of investment to capital stock; Cash Flow is the ratio of cash flow to capital stock; Tobin's $q$ is the ratio of market value of assets to capital stock; $F F 2(3-6)$ is a dummy equal to 1 if a company has a negative deviation from its target larger than at least $10 \%$ of all undershooting firms for 2(3-6) consecutive years, and 0 otherwise. $F F(5 \%)$ is a dummy equal to 1 if a company has a negative deviation from its target larger than at least $5 \%$ for at least three consecutive years. $F F(25 \%)$ is a dummy equal to 1 if a company has a negative deviation from its target larger than at least $25 \%$ for at least three consecutive years. $F F(1.5 S D)$ is a dummy equal to 1 if a company has a negative deviation from its target larger than at least 1.5 units of standard deviation for at least three consecutive years. We conducted all estimations using the GMM-DIFF. We show regression coefficients with heteroskedasticity robust standard errors. $p$-Values are provided in parentheses.

\begin{tabular}{|c|c|c|c|c|c|}
\hline \multicolumn{6}{|c|}{ Panel A. FF Dummies Based on the SDC Status Spanning between Two and Six Years } \\
\hline & FF2 & FF3 & FF4 & FF5 & FF6 \\
\hline Investment $_{t-1}$ & $\begin{array}{c}0.169 \\
(0.000)\end{array}$ & $\begin{array}{c}0.176 \\
(0.000)\end{array}$ & $\begin{array}{c}0.179 \\
(0.000)\end{array}$ & $\begin{array}{c}0.176 \\
(0.000)\end{array}$ & $\begin{array}{c}0.175 \\
(0.000)\end{array}$ \\
\hline Cash Flow t-1 $_{1}$ & $\begin{array}{c}0.112 \\
(0.000)\end{array}$ & $\begin{array}{c}0.119 \\
(0.000)\end{array}$ & $\begin{array}{c}0.100 \\
(0.000)\end{array}$ & $\begin{array}{c}0.099 \\
(0.001)\end{array}$ & $\begin{array}{c}0.096 \\
(0.000)\end{array}$ \\
\hline Tobin's $Q$ & $\begin{array}{c}0.003 \\
(0.012)\end{array}$ & $\begin{array}{c}0.003 \\
(0.007)\end{array}$ & $\begin{array}{c}0.003 \\
(0.010)\end{array}$ & $\begin{array}{c}0.003 \\
(0.005)\end{array}$ & $\begin{array}{c}0.003 \\
(0.006)\end{array}$ \\
\hline$F F$ & $\begin{array}{c}0.031 \\
(0.000)\end{array}$ & $\begin{array}{c}0.034 \\
(0.000)\end{array}$ & $\begin{array}{c}0.031 \\
(0.000)\end{array}$ & $\begin{array}{c}0.026 \\
(0.000)\end{array}$ & $\begin{array}{c}0.033 \\
(0.014)\end{array}$ \\
\hline FF $^{*}$ Cash Flow $_{t-1}$ & $\begin{array}{c}-0.033 \\
(0.000)\end{array}$ & $\begin{array}{c}-0.028 \\
(0.000)\end{array}$ & $\begin{array}{r}-0.035 \\
(0.001)\end{array}$ & $\begin{array}{c}-0.022 \\
(0.006)\end{array}$ & $\begin{array}{r}-0.066 \\
(0.045)\end{array}$ \\
\hline Observations & 26,626 & 26,626 & 26,626 & 26,626 & 26,626 \\
\hline Number of Firms & 2,541 & 2,541 & 2,541 & 2,541 & 2,541 \\
\hline Firm Fixed Effects & Yes & Yes & Yes & Yes & Yes \\
\hline Year Fixed Effects & Yes & Yes & Yes & Yes & Yes \\
\hline Economic Impact (mean) & 32.37 & 37.25 & 31.95 & 28.36 & 27.90 \\
\hline
\end{tabular}

Panel B. FF Dummies Based on Different Thresholds in the Deviation from Target

\begin{tabular}{lccc}
\hline \hline & FF3(5\%) & FF3(25\%) & FF3(1.5 SD) \\
\hline Investment $_{t-1}$ & 0.194 & 0.181 & 0.195 \\
& $(0.000)$ & $(0.000)$ & $(0.000)$ \\
Cash Flow $_{t-1}$ & 0.118 & 0.081 & 0.096 \\
& $(0.000)$ & $(0.000)$ & $(0.000)$ \\
Tobin's $Q$ & 0.003 & 0.003 & 0.003 \\
& $(0.000)$ & $(0.000)$ & $(0.000)$ \\
FF & 0.037 & 0.035 & 0.033 \\
& $(0.000)$ & $(0.000)$ & $(0.000)$ \\
FF $^{*}$ Cash Flow $_{t-1}$ & -0.078 & -0.022 & -0.023 \\
& $(0.035)$ & $(0.000)$ & $(0.000)$ \\
Observations & 26,626 & 26,626 & 26,626 \\
Number of Firms & 2,541 & 2,541 & 2,541 \\
Firm Fixed Effects & Yes & Yes & Yes \\
Year Fixed Effects & Yes & Yes & Yes \\
Economic Impact (mean) & 30.43 & 39.79 & 37.04 \\
\hline \hline
\end{tabular}


impact of FF3. This is probably due to the fact that very small deviations are simply affected by noise, which, in turn, waters down the result. ${ }^{10}$

\section{E. The Role of Internal Funds}

A number of studies emphasize the importance of cash holding in obtaining financial flexibility and reducing underinvestment problems. Faulkender and Wang (2006) find that the marginal value of cash is substantially higher for constrained than for unconstrained firms. They also report that this result is stronger for firms with high growth options. In a recent paper, Denis and Sibilkov (2010) report that higher levels of financial slack allow constrained firms to undertake value increasing projects. Their results also tally with Faulkender and Wang (2006) in that cash holdings are more valuable for constrained than for unconstrained firms. In a similar vein, Gamba and Triantis (2008) propose a theoretical model in which firms can mitigate the negative effect of financial constraints through an appropriate liquidity policy, although their model expressly neglects agency costs. Alternatively, Harford (1999) finds that cash rich companies are more exposed to the overinvestment problem, and that they tend to make value-decreasing acquisitions.

We try to tackle this issue in two ways. First, we include cash and a proxy for excess cash into our investment model to control for the potential impact of financial slack. In the first column of Panel A, Table V, we substitute cash flow with cash. In the second column, we include them both in the regression. In the third and fourth columns, we repeat the same exercise, but we include a proxy for excess cash rather than the level of cash. To do that, we run an auxiliary cash regression similar to Opler et al. (1999) to obtain predicted cash and classify firms with positive deviations from target as cash rich. A similar procedure is adopted in Harford (1999) and Denis and Sibilkov (2010). We then use this proxy for cash richness in the investment model to control for the fact that some firms may use excess cash rather than leverage to attain financial flexibility to invest.

The results from these tests are in line with the previous evidence corroborating our original hypothesis that (at least) the firms we define as FF are using spare debt capacity as their main vehicle to attain financial flexibility and enhance their investment ability. Both cash and excess cash are statistically significant and with the expected sign, but across all specifications, the economic impact of the FF status remains similar to the previous estimates.

Second, we try to test for the role of internal funds in an alternative way. By construction, when predicted leverage is calculated in our baseline model and low leverage and FF firms are classified, the cash position of the firm is not directly controlled for as it is not among the variables in the baseline model. If cash (or excess cash) were to be an important determinant of leverage decisions (especially for those firms in stronger need of financial flexibility), this would end up in the residual of the model. Thus, the estimated FF dummy would already "contain" information regarding the cash position and the previous test may not discriminate between the role played by the internal funds and that of spare debt capacity as they are both embedded in the FF dummy. Therefore, to further test the robustness of our results, we estimate a target leverage model augmented by a variety of other factors that may help firms achieve financial flexibility. We include the firm's cash holding, along with the maturity of its debt and its dividend payout (Column 2, Table I). The residual of the leverage model is now "cleaned" of this potential

\footnotetext{
${ }^{10}$ In an unreported test, we replicate the above analysis by transforming leverage in difference from industry median to better control for potential industry effects in determining spare debt capacity. The results are similar to those reported above.
} 


\section{Table V. Robustness Tests: The Role of Internal Funds}

This table presents GMM results for the q-model of investment with financial flexibility status dummies computed from various alternative specifications. In Panel A, the Investment model is augmented with cash variables. The dependent variable is Investment, defined as the ratio of investment to capital stock; Cash Flow is the ratio of cash flow to capital stock; Tobin's $q$ is the ratio of the market value of assets to capital stock; $F F 3$ is a dummy equal to one if a company has a negative deviation from its target larger than at least $10 \%$ of all undershooting firms for three consecutive years, and zero otherwise; Cash is the ratio of total cash and equivalents to total assets; Excess Cash is computed using an auxiliary cash regression to obtain predicted cash, and to classify, as cash rich, those firms with positive deviations from the target. In Panel $\mathrm{B}$, the FF dummy is obtained using alternative specifications of the leverage model. Column One reports results with the FF dummy derived from the extended leverage model (Table I, Column 2). In Column 2, we repeat the same exercise, but we use a proxy for excess cash rather than cash, as described above. In Column 3, we run the leverage model substituting leverage with Net Debt defined as leverage minus cash. In Column 4 , we run the extended leverage model augmented with a proxy for cash flow volatility ( $C f$ Volat) defined as the standard deviation of cash flow in the previous five years scaled by average total assets in the same period. The last column (Percentile) reports results where the SDC dummy is one when observed leverage is in the bottom $20 \%$ of the distribution. We conduct all estimations using the GMM-DIFF. We show regression coefficients with heteroskedasticity robust standard errors. $p$-Values are provided in parentheses.

\begin{tabular}{|c|c|c|c|c|}
\hline \multicolumn{5}{|c|}{ Panel A. The Role of Internal Funds in the Investment Model } \\
\hline & Cash & $\begin{array}{l}\text { Cash Plus } \\
\text { Cash Flow }\end{array}$ & $\begin{array}{c}\text { Excess } \\
\text { Cash }\end{array}$ & $\begin{array}{c}\text { Excess Cash Plus } \\
\text { Cash Flow }\end{array}$ \\
\hline Investment $_{t-1}$ & $\begin{array}{c}0.193 \\
(0.000)\end{array}$ & $\begin{array}{c}0.190 \\
(0.000)\end{array}$ & $\begin{array}{c}0.181 \\
(0.000)\end{array}$ & $\begin{array}{c}0.159 \\
(0.000)\end{array}$ \\
\hline Tobin's $Q$ & $\begin{array}{c}0.003 \\
(0.000)\end{array}$ & $\begin{array}{c}0.002 \\
(0.003)\end{array}$ & $\begin{array}{c}0.003 \\
(0.000)\end{array}$ & $\begin{array}{c}0.002 \\
(0.004)\end{array}$ \\
\hline$F F 3$ & $\begin{array}{c}0.031 \\
(0.000)\end{array}$ & $\begin{array}{c}0.041 \\
(0.000)\end{array}$ & $\begin{array}{c}0.031 \\
(0.000)\end{array}$ & $\begin{array}{c}0.035 \\
(0.000)\end{array}$ \\
\hline Cash $_{t-1}$ & $\begin{array}{c}0.035 \\
(0.001)\end{array}$ & $\begin{array}{c}0.041 \\
(0.020)\end{array}$ & & \\
\hline$F F 3^{*}$ Cash $_{t-1}$ & $\begin{array}{r}-0.030 \\
(0.087)\end{array}$ & & & \\
\hline Cash Flow $_{t-1}$ & & $\begin{array}{c}0.127 \\
(0.000)\end{array}$ & & $\begin{array}{c}0.112 \\
(0.000)\end{array}$ \\
\hline FF3* Cash Flow $_{t-1}$ & & $\begin{array}{c}-0.068 \\
(0.026)\end{array}$ & & $\begin{array}{r}-0.050 \\
(0.030)\end{array}$ \\
\hline Excess Cash $_{t-1}$ & & & $\begin{array}{c}0.024 \\
(0.057)\end{array}$ & $\begin{array}{c}0.009 \\
(0.094)\end{array}$ \\
\hline FF3 $^{*}$ Excess Cash Cl-1 & & & $\begin{array}{r}-0.017 \\
(0.009)\end{array}$ & \\
\hline Observations & 26,626 & 26,626 & 26,626 & 26,626 \\
\hline Number of Firms & 2,541 & 2,541 & 2,541 & 2,541 \\
\hline Firm Fixed Effects & Yes & Yes & Yes & Yes \\
\hline Year Fixed Effects & Yes & Yes & Yes & Yes \\
\hline Economic Impact (mean) & 32.36 & 37.64 & 39.38 & 35.01 \\
\hline
\end{tabular}

(Continued)

disturbance, and we proceed to reclassify low leverage and FF companies. Table V, Panel B, Column 1 reports the results of this exercise.

Once again, our findings lend no support to the view that the "missing link" in our leverage model is cash richness. The results in Column 1 are in line with our baseline specification, and 
Table V. Robustness Tests: The Role of Internal Funds (Continued)

\begin{tabular}{lccccc}
\hline \multicolumn{5}{c}{ Panel B. The Role of Internal Funds in Determining the Flexibility Status } \\
\hline \hline & Extended Model & Excess Cash & Net Debt & Cf Volat & Percentile \\
\hline Investment $_{t-1}$ & 0.176 & 0.165 & 0.162 & 0.135 & 0.190 \\
& $(0.000)$ & $(0.000)$ & $(0.000)$ & $(0.000)$ & $(0.000)$ \\
Cash Flow $_{t-1}$ & 0.119 & 0.129 & 0.136 & 0.151 & 0.074 \\
& $(0.000)$ & $(0.000)$ & $(0.000)$ & $(0.000)$ & $(0.001)$ \\
Tobin's $Q$ & 0.003 & 0.004 & 0.005 & 0.007 & 0.003 \\
& $(0.007)$ & $(0.015)$ & $(0.008)$ & $(0.002)$ & $(0.000)$ \\
FF3 & 0.033 & 0.034 & 0.037 & 0.040 & 0.049 \\
& $(0.000)$ & $(0.000)$ & $(0.000)$ & $(0.000)$ & $(0.000)$ \\
FF3* Cash Flow & & -0.050 & -0.069 & -0.087 & -0.121 \\
& -0.028 & $(0.014)$ & $(0.002)$ & $(0.008)$ & $(0.005)$ \\
Observations & $(0.000)$ & 26,626 & 26,626 & 26,626 & 26,626 \\
Number of firms & 26,626 & 2,541 & 2,541 & 2,541 & 2,541 \\
Firm Fixed Effects & 2,541 & Yes & Yes & Yes & Yes \\
Year Fixed Effects & Yes & Yes & Yes & Yes & Yes \\
Economic Impact (mean) & 35.98 & 32.57 & 32.35 & 32.33 & 36.41 \\
\hline \hline
\end{tabular}

the economic impact of the FF proxy is very close to our baseline result, $36 \%$. We also replicate this test replacing cash holding with excess cash (as defined above) in the leverage equation, and the results do not vary significantly (Panel B, Column 2).

Further, a number of papers argue that cash positions are important in determining net debt. For instance, Bates et al. (2009) document an increasing tendency by US firms to hoard cash, which may have important implications for their capital structure. To support their argument, they report a significant decrease in leverage when looking at net debt measures (leverage minus cash) as opposed to the more traditional measures of debt to assets. Data inspection reveals almost identical trends for UK firms to those reported by Bates et al. (2009). Therefore, we try to address this concern by re-estimating the extended leverage model using the definition of net debt suggested by Bates et al. (2009). ${ }^{11}$ The results of the investment analysis offer little support for amending our original specification. The FF dummy and the interaction term have a similar effect on investment, and the economic impact is similar to our baseline specification using leverage, $32 \%$ (Table V, Panel B, Column 3).

In their recent paper, DeAngelo and DeAngelo (2007) argue that firms with more unpredictable earnings may value financial flexibility more than other firms. Although our descriptive analysis finds little support for this view, we try to control for this possibly omitted variable in our leverage equation. We augment the leverage model with the volatility of cash flow to control for this potential influence. The results, in the fourth column of Panel B, again confute this alternative explanation of our results. The FF dummy is still positive and significant, while the interaction term is significant and negative. The estimated economic impact is in line with the previous figures $(32 \%)$.

A final criticism of our approach may be that the leverage model is still somehow mis-specified, and that this affects the estimated target, deviations from it, and the classification of firms. A number of papers have run similar analyses to ours relying on the statistical distribution of the

\footnotetext{
${ }^{11}$ We thank Mara Faccio for suggesting this robustness test.
} 
variable under study to discriminate high/low values. For instance, Minton and Wruck (2001) classify a firm as low leverage if its value is in the bottom $20 \%$ of all firms for five consecutive years. Therefore, to control for this potential issue, we re-estimate all our investment regressions classifying firms as low leverage as do Minton and Wruck (2001). The results in the last column of Table V, Panel B indicate that the basic story behind our results holds. The financial flexibility attained through a conservative leverage policy seems to enable firms to invest significantly more in the following years, irrespective of the definition of leverage. ${ }^{12}$

\section{F. Long Run Performance Analysis}

As we discussed above, some papers have suggested that managers have a taste for low debt ratios as a consequence of their lack of diversification (Fama, 1980). However, managers may also use high leverage instrumentally to reduce the risk of takeover (Berger et al., 1997) or to pursue empire building projects (Zwiebel, 1996) ${ }^{13}$ In other words, the main determinant of both conservative leverage and high investment may be managerial entrenchment, rather than financial flexibility. To sort out these various potential influences, we use three alternative tests.

First, in an attempt to control for equity agency costs, we re-run all the analysis beginning with the leverage model and including ownership and governance characteristics (Table I, Column 3). The results (not reported for brevity) are in line with those presented thus far. For instance, the economic impact of the FF dummy calculated on three years of SDC is approximately $38 \%$.

Second, we examine the impact of financial flexibility on long run performance. This allows us to test directly whether the flexibility policy and abnormal investments are good for shareholders. If the FF companies invest more because of managerial entrenchment (i.e., empire building), then we should find that they underperform in the long run. Conversely, if the increase in investment is value-enhancing, then we should see these companies outperforming the market.

We proceed in two steps. First, we test for long run performance after companies acquire FF status. Second, we perform the same test, but we study long run performance after FF firms make abnormal investments as defined above.

Table VI reports time-series estimates of $a_{p F F}$ from both the CAPM and the Fama and French (1993) model. Financially flexible firms are defined over three years of low leverage status. We present the results with FF status calculated using both the targeting and the percentile method (Panel A).

Overall, the results indicate that, after acquiring FF status, FF firms do outperform across different long run measures (24,36, and 60 months, Panel A). This supports our original hypothesis that the low leverage policy we capture creates value, and is indeed driven by an efficient forwardlooking investment strategy, rather than managerial entrenchment behavior. For instance, when we consider the Fama and French (1993) three-factor model, FF companies outperform the market by an average of $30 \mathrm{bps}$ per month. In economic terms, this represents a material excess return of about $7.1 \%$ in the first two years. Further results on long run performance following abnormal investments provide strong support for this interpretation (Panel B). Jensen's (1986) alpha is always positive and statistically significant, irrespective of the method followed to classify FF

\footnotetext{
${ }^{12}$ We also test, but do not report for brevity, our investment hypotheses using the Euler equation as opposed to the q-model. Also, in another unreported test, we combine investment in fixed assets with investments in R\&D to obtain a proxy for "total investment." All results are in line with those presented in the tables.

${ }^{13}$ In a recent paper, Zhang (2009) discusses the important role that debt (along with incentive compensation) has in limiting overinvestment.
} 


\section{Table VI. Long-Run Performance}

This table presents time-series estimates of alphas from CAPM and Fama and French (1993) three-factor regressions for equally weighted portfolios of financially flexible firms (FF3).

$$
\begin{aligned}
& R_{p F F, t}-R_{f, t}=\alpha_{p F F}+\beta_{p F F}\left(R_{m, t}-R_{f, t}\right)+\varepsilon_{p F F, t} \\
& R_{p F F, t}-R_{f, t}=a_{p F F}+b_{p F F}\left(R_{m, t}-R_{f, t}\right)+s_{p F F} S M B_{t}+h_{p F F} H M L_{t}+\varepsilon_{p F F, t} .
\end{aligned}
$$

$R p F F, t$ denotes the month $t$ return of the equally weighted portfolio of all firms identified as financially flexible (pFF) in the preceding 24 (36 or 60) months; $R f, t$ is the United Kingdom three-month Treasury bill rate converted to a monthly rate of return; $R m, t$ represents the return on the FTSE All Share Index in month $t$; $S M B t(H M L t)$ is the return difference between a portfolio of small and large (high and low book-to-market) firms, which are proxied by the FTSE Small Cap and FTSE 100 Indexes (FTSE Global Value and FTSE Global Growth Indexes). $F F$ refers to Financially Flexible firms. It is a dummy equal to one if a company has a negative deviation from its target larger than at least $10 \%$ of all undershooting firms for three consecutive years. Abnormal Investment is defined over a pattern of three years of industry-adjusted investment data. The average value of investments is calculated in the extreme years (i.e., $\left.\left(\operatorname{AdjI}_{t-1}+A d j I_{t+1}\right) / 2\right)$. Thus, there is a spike in this pattern only if the investment value in the central year is at least twice the average of the

\begin{tabular}{|c|c|c|c|c|}
\hline \multirow[b]{2}{*}{ Window } & \multicolumn{2}{|c|}{ Targeting Method } & \multicolumn{2}{|c|}{ Percentile Method } \\
\hline & $\operatorname{CAPM} \alpha_{i}$ & Fama and French $a_{i}$ & $\operatorname{CAPM} \alpha_{i}$ & Fama and French $a_{i}$ \\
\hline \multicolumn{5}{|c|}{ Panel A. Long-Run Performance After Financial Flexibility Status is Acquired } \\
\hline+24 months & $\begin{array}{l}0.00323 \\
(0.015)\end{array}$ & $\begin{array}{l}0.00297 \\
(0.000)\end{array}$ & $\begin{array}{l}0.00364 \\
(0.011)\end{array}$ & $\begin{array}{l}0.00335 \\
(0.007)\end{array}$ \\
\hline+36 months & $\begin{array}{l}0.00287 \\
(0.025)\end{array}$ & $\begin{array}{l}0.00246 \\
(0.003)\end{array}$ & $\begin{array}{l}0.00346 \\
(0.014)\end{array}$ & $\begin{array}{l}0.00315 \\
(0.006)\end{array}$ \\
\hline+60 months & $\begin{array}{l}0.00245 \\
(0.043)\end{array}$ & $\begin{array}{l}0.00168 \\
(0.030)\end{array}$ & $\begin{array}{l}0.00307 \\
(0.021)\end{array}$ & $\begin{array}{l}0.00217 \\
(0.020)\end{array}$ \\
\hline \multicolumn{5}{|c|}{ Panel B. Long-Run Performance After Abnormal Investments } \\
\hline +24 months & $\begin{array}{l}0.00380 \\
(0.008)\end{array}$ & $\begin{array}{l}0.00552 \\
(0.025)\end{array}$ & $\begin{array}{l}0.00405 \\
(0.008)\end{array}$ & $\begin{array}{l}0.00240 \\
(0.048)\end{array}$ \\
\hline+36 months & $\begin{array}{l}0.00353 \\
(0.011)\end{array}$ & $\begin{array}{l}0.00438 \\
(0.046)\end{array}$ & $\begin{array}{l}0.00389 \\
(0.008)\end{array}$ & $\begin{array}{l}0.00208 \\
(0.045)\end{array}$ \\
\hline +60 months & $\begin{array}{l}0.00344 \\
(0.010)\end{array}$ & $\begin{array}{l}0.00232 \\
(0.044)\end{array}$ & $\begin{array}{l}0.00373 \\
(0.007)\end{array}$ & $\begin{array}{l}0.00185 \\
(0.038)\end{array}$ \\
\hline
\end{tabular}
extremes. $p$-Values are in parentheses.

firms. ${ }^{14}$ The economic impact is even stronger in this case. FF firms seem to outperform the market by approximately $13.24 \%$.

Third, in Table VII we examine the changes in profitability following the acquisition of the FF status (Panel A) and following the creation of abnormal investment (Panel B). The results confirm our previous evidence. Companies appear to experience an increase in their profitability of more than $18 \%$ after the FF status has been acquired but, more importantly, they are able to generate a remarkable boost of about $38 \%$ in operating performance within two years from the time of their abnormal investment.

${ }^{14}$ For robustness purposes, we repeated the analysis using an alternative definition of abnormal investment where this is defined as investments above industry median. The results are largely unaltered. 
Table VII. Long-Run Profitability

This table presents percentage changes in Profitability (operating performance) of FF firms before and after the FF status is acquired (Panel A) or after abnormal investments have been made (Panel B). FF refers to Financially Flexible firms. It is a dummy equal to 1 if a company has a negative deviation from its target larger than at least $10 \%$ of all undershooting firms for three consecutive years. Abnormal Investment is defined over a pattern of three years of industry-adjusted investment data. The average value of investments is calculated in the extreme years (i.e., $\left(A d j I_{t-1}+A d j I_{t+1}\right) / 2$ ). Thus, there is a spike in this pattern only if the investment value in the central year is at least twice the average of the extremes. Profitability is the ratio of earnings before interest, tax, and depreciation (EBITD) to total assets.

\begin{tabular}{|c|c|c|c|c|c|c|}
\hline & $\begin{array}{c}\text { Level at } \\
t-1\end{array}$ & $\begin{array}{c}\% \text { Change } \\
\text { Between } \\
t-1 \text { and } \\
t+1\end{array}$ & $\begin{array}{l}\text { Test of Difference } \\
\text { in Means } t-1 \\
\text { versus } t+1 \\
\text { ( } p \text {-value) }\end{array}$ & $\begin{array}{c}\% \text { Change } \\
\text { Between } \\
t-1 \\
\text { and } t+2\end{array}$ & $\begin{array}{c}\text { Test } \\
\text { in } \\
\text { ve }\end{array}$ & $\begin{array}{l}\text { of Difference } \\
\text { Means } t-1 \\
\text { rsus } t+2 \\
\text { (p-value) }\end{array}$ \\
\hline \multicolumn{7}{|c|}{ Panel A. Profitability Around the Financial Flexibility Status Acquisition } \\
\hline $\begin{array}{l}\text { Profitability } \\
\text { Targeting } \\
\text { Method }\end{array}$ & 0.094 & $13.81 \%$ & $(0.000)$ & $18.32 \%$ & & $(0.000)$ \\
\hline $\begin{array}{l}\text { Profitability } \\
\text { Percentile } \\
\text { Method }\end{array}$ & 0.110 & $4.71 \%$ & $(0.000)$ & $10.51 \%$ & & $(0.000)$ \\
\hline \multicolumn{7}{|c|}{ Panel B. Profitability Around the Abnormal Investments } \\
\hline $\begin{array}{l}\text { Profitability } \\
\text { Targeting } \\
\text { Method }\end{array}$ & 0.092 & $18.10 \%$ & $(0.000)$ & $38.32 \%$ & & $(0.000)$ \\
\hline $\begin{array}{c}\text { Profitability } \\
\text { Percentile } \\
\text { Method }\end{array}$ & 0.118 & $771 \%$ & $(0.000)$ & $29.78 \%$ & & $(0.000)$ \\
\hline
\end{tabular}

\section{Conclusion}

In this paper, we study the interaction between financial flexibility and investment ability. Our argument, based on the ideas of Modigliani and Miller (1963) and Myers (1984), maintains that in the presence of financial constraints, firms that anticipate valuable growth options in the future respond by accumulating reserves of borrowing power. Through a conservative leverage policy, companies maintain a degree of financial flexibility that allows them to have better access to the external market when faced with positive shocks to their investment opportunity set. Recent survey studies regarding the determinants of capital structure give strong support to this view in that financial flexibility is systematically reported as the most important factor on which CFOs base their leverage decision.

Our intertemporal investigation of firm behavior corroborates these hypotheses. After a period of leverage conservatism, FF firms significantly increase their capital expenditures with respect to previous years. Most notably, we identify a sharp increase in their abnormal investments. Our results indicate that firms finance this investment with positive net debt issues. 
The results of our empirical tests are also consistent with our predictions. We report strong evidence of significant links between financing and investment decisions. Our findings indicate that after a period of spare debt capacity, FF firms are able to invest significantly more. We demonstrate that the impact of the flexibility factor is sizeable in economic terms. An average firm is able to increase its investment by approximately $37 \%$. This is an important result, and it provides a rationale for many firms' apparent conservative leverage behavior (Graham, 2000; Minton and Wruck, 2001; Almeida et al., 2009).

We also perform a long run performance analysis to test whether these investments are an expression of "empire building," as opposed to genuinely value-enhancing. We consistently find that firms classified as FF tend to outperform the market and experience an increase in operating performance in subsequent years. This result is robust to the classification method followed to classify firms as FF.

In a recent working paper, Denis and McKeon (2009) report similar results to ours. They report evidence that companies use spare debt capacity to meet large positive shocks to their investment opportunity sets. Subsequently, and similarly to our sample of UK companies, their set of US firms (slowly) rebalance their leverage toward the long-term target.

Overall, our results offer strong empirical support for the survey evidence, and indicate that financial flexibility, in the form of untapped reserves of borrowing power, is a crucial missing link in capital structure theory. In particular, our evidence is broadly consistent with DeAngelo et al. (2010). In their model, firms use spare debt capacity to respond to "funding needs associated with imperfectly anticipated investment shocks, while allowing them to economize on the costs of issuing equity and of maintaining cash balances." This is consistent with a "modified" tradeoff model in which the optimal debt level for a firm incorporates the ex ante opportunity cost of borrowing (i.e., future underinvestment). The firm's ex ante optimum debt level reflects the value of the option of using debt capacity to borrow ex post and to move away, deliberately but temporarily, from target leverage to meet imperfectly anticipated funding needs.

\section{References}

Almeida, H., M. Campello, and M. Weisbach, 2009, "Corporate Financial and Investment Policies When Future Financing is Not Frictionless," Journal of Corporate Finance, forthcoming.

Alti, A., 2003, "How Sensitive is Investment to Cash Flow When Financing is Frictionless?" Journal of Finance 58, 707-722.

Altman, E.I., 1968, "Financial Ratios, Discriminant Analysis and the Prediction of Corporate Bankruptcy," Journal of Finance 23, 589-609.

Arellano, M. and S. Bond, 1991, "Some Tests of Specification for Panel Data: Monte Carlo Evidence and an Application to Employment Equations," Review of Economic Studies 58, 277-297.

Bancel, F., N. Bhattacharyya, and U.R. Mittoo, 2009, "Cross-Country Determinants of Payout Policy: European Firms," in H.K. Baker, Ed., Dividends and Dividend Policy, John Wiley, Kolb Series in Finance, 71-93.

Bancel, F. and U.R. Mittoo, 2004, "The Determinants of Capital Structure Choice: A Survey of European Firms," Financial Management 33, 103-132.

Bates, T.W., K.M. Kahle, and R.M. Stulz, 2009, "Why Do U.S. Firms Hold So Much More Cash than They Used to?" Journal of Finance 64, 1985-2021. 
Berger, P.G., E. Ofek, and D.L. Yermak, 1997, "Managerial Entrenchment and Capital Structure Decisions," Journal of Finance 52, 1411-1438.

Blundell, R. and S. Bond, 1998, "Initial Conditions and Moment Restrictions in Dynamic Panel Data Models," Journal of Econometrics 87, 115-143.

Bond, S., J.A. Elston, J. Mairesse, and B. Mulkay, 2003, "Financial Factors and Investment in Belgium, France, Germany, and the United Kingdom: A Comparison Using Company Panel Data," Review of Economics and Statistics 85, 153-165.

Brounen, D., A. De Jong, and K. Koedijk, 2004, "Corporate Finance in Europe: Confronting Theory with Practice," Financial Management 33, 71-101.

Brown, J.R. and M. Petersen, 2009, "Why Has the Investment-Cash Flow Sensitivity Declined So Sharply? Rising R\&D and Equity Market Developments," Journal of Banking \& Finance 33, 971984.

Cleary, S., 1999, “The Relation between Firm Investment and Financial Status,” Journal of Finance 54, 673-692.

Cleary, S., P. Povel, and M. Raith, 2007, “The U-Shaped Investment Curve: Theory and Evidence,” Journal of Financial and Quantitative Analysis 42, 1-39.

Datta, S., M. Iskandar-Datta, and K. Raman, 2005, "Managerial Stock Ownership and the Maturity Structure of Corporate Debt," Journal of Finance 60, 2333-2350.

DeAngelo, H. and L. DeAngelo, 2007, “Capital Structure, Payout Policy and Financial Flexibility,” SSRN Working paper 916093

DeAngelo, H., L. DeAngelo, and T. Whited, 2010, "Capital Structure Dynamics and Transitory Debt," SSRN Working paper 1262464.

Denis, D.J. and D.K. Denis, 1993, "Managerial Discretion, Organizational Structure and Corporate Performance," Journal of Accounting and Economics 16, 209-236.

Denis, D.J. and S.B. McKeon, 2009, "Debt Financing and Financial Flexibility: Evidence from Proactive Leverage Increases,” SSRN Working paper 1361171.

Denis, D.J. and V. Sibilkov, 2010, "Financial Constraints, Investment, and the Value of Cash Holdings," Review of Financial Studies 23, 247-269.

Fama, E.F., 1980, “Agency Problems and the Theory of the Firm,” Journal of Political Economy 88, 288-307.

Fama, E.F. and K.R. French, 1993, “Common Risk Factors in the Returns on Stocks and Bonds,” Journal of Financial Economics 33, 3-56.

Faulkender, M.H. and M. Petersen, 2006, “Does the Source of Capital Affect Capital Structure?” Review of Financial Studies 19, 45-79.

Faulkender, M.H. and R. Wang, 2006, “Corporate Financial Policy and the Value of Cash,” Journal of Finance 61, 1957-1990.

Flannery, M.J. and K.P. Rangan, 2006, "Partial Adjustment Toward Target Capital Structures," Journal of Financial Economics 79, 469-506.

Frank, M.Z. and V.K. Goyal, 2009, “Capital Structure Decisions: Which Factors are Reliably Important?” Financial Management 38, 1-37.

Gamba, A. and A.J. Triantis, 2008, “The Value of Financial Flexibility,” Journal of Finance 63, 22632296. 
Graham, J., 2000, “How Big Are the Tax Benefits of Debt?” Journal of Finance 55, 1901-1942.

Graham, J.R. and C.R. Harvey, 2001, "The Theory and Practice of Corporate Finance: Evidence from the Field," Journal of Financial Economics 60, 187-243.

Harford, J., 1999, “Corporate Cash Reserves and Acquisitions,” Journal of Finance 54, 1969-1997.

Iona, A., L. Leonida, and A. Ozkan, 2004, "Determinants of Financial Conservatism: Evidence from Low Leverage and Cash-Rich UK Firms," University of York Discussion Papers in Economics.

Jagannathan, M., C.P. Stephens, and M.S. Weisbach, 2000, "Financial Flexibility and the Choice Between Dividends and Stock Repurchases," Journal of Financial Economics 57, 355-384.

Jensen, M.C., 1986, “Agency Costs of Free Cash Flow, Corporate Finance and Takeovers," American Economic Review 76, 323-339.

Johnson, S.A., 2003, "Debt Maturity and the Effects of Growth Opportunities and Liquidity Risk on Leverage," Review of Financial Studies 16, 209-236.

Lemmon, M.L., M. Roberts, and J.F. Zender, 2008, "Back to the Beginning: Persistence and the CrossSection of Corporate Capital Structure," Journal of Finance 63, 1575-1608.

Marchica, M.T., 2007, "On the Relevance of Ownership Structure in Determining the Maturity of Debt," SSRN Working paper 1101103.

Mayer, C. and O. Sussman, 2004, “A New Test of Capital Structure,” CEPR Discussion paper No. 4239.

Mikkelson, W.H. and M.M. Partch, 2003, "Do Persistent Large Cash Reserves Hinder Performance?" Journal of Financial and Quantitative Analysis 38, 275-294.

Minton, B.A. and K.H. Wruck, 2001, "Financial Conservatism: Evidence on Capital Structure from Low Leverage Firms," Dice Center Working paper.

Modigliani, F. and M. Miller, 1963, "Corporate Income Taxes and the Cost of Capital: A Correction," American Economic Review 53, 433-443.

Mura, R., 2007, “Firm Performance: Do Non-Executive Directors Have Minds of their Own? Evidence from UK Panel Data," Financial Management 37, 81-112.

Myers, S.C., 1984, “The Capital Structure Puzzle,” Journal of Finance 39, 575-592.

Opler, T., L. Pinkowitz, R. Stulz, and R. Williamson, 1999, "The Determinants and Implications of Cash Holdings," Journal of Financial Economics 52, 3-46.

Oswald, D. and S. Young, 2004, "What Role Taxes and Regulation? A Second Look at Open Market Share Buyback Activity in the UK," Journal of Business Finance and Accounting 31, 257292.

Pinegar, M. and L. Wilbricht, 1989, "What Managers Think of Capital Structure: A Survey," Financial Management 18, 82-91.

Powers, E. and S. Tsyplakov, 2008, "What Is the Cost of Financial Flexibility? Theory and Evidence for Make-Whole Call Provisions," Financial Management 37, 485-512.

Price Waterhouse Coopers, Dec. Issues, Corporate Register, London, UK, HS Financial Publishing.

Rajan, R.G. and L. Zingales, 1995, "What Do We Know about Capital Structure? Some Evidence from International Data," Journal of Finance 50, 1421-1460.

Strebulaev, I.A. and B. Yang, 2008, “The Mystery of Zero-Leverage Firms,” SSRN Working paper 890719. 
Tsyplakov, S., 2008, "Investment Frictions and Leverage Dynamics," Journal of Financial Economics 89, 423-443.

Wooldridge, J.M., 2000, Introductory Econometrics, Boston, MA, South-Western College Publishing.

Zhang, Y., 2009, “Are Debt and Incentive Compensation Substitutes in Controlling the Free Cash Flow Agency Problem?" Financial Management 38, 507-541.

Zwiebel, J., 1996, "Dynamic Capital Structure under Managerial Entrenchment," American Economic Review 86, 1197-1215. 


\section{Queries}

Q1 Author: Reference Denis and Sibilkov (2009) has not been included in the Reference List, please supply full publication details.

Q2 Author: A running head short title was not supplied; please check if this one is suitable and, if not, please supply a short title that can be used instead.

Q3 Author: Please update reference Almeida et al. (2009). 